Full-text Available Online at www.ajol.info and www.bioline.org.br/ja
J. Appl. Sci. Environ. Manage. Sept, 2015

Vol. 19 (3) 495 - 499

\title{
Determination of Total Potency Equivalent Concentration (Tpec) of Carcinogenic Polycyclic Aromatic Hydrocarbons (Cpahs) In Soils of Bodo-City
}

\author{
${ }^{* 1}$ IWUOHA, GN; ${ }^{1}$ NWIGOO, J. ${ }^{1}$ ONOJAKE, MC \\ ${ }^{I}$ Department of Pure and Industrial Chemistry, Faculty of Chemical Sciences, College of Natural and Applied Sciences, University of Port \\ Harcourt
}

KEYWORDS; TEQ, TEF, PEF, cPAHs, BaP, Bodo, risk assessment

\begin{abstract}
The aim of this paper is to report the determination of Total potency equivalent concentration (TPEC) of Carcinogenic polycyclic aromatic hydrocarbons (cPAHs) in soil samples from Bodo area in Ogoniland using the Toxicity Equivalent Factor (TEF) model. Gas Chromatography GC HP 5870 with FID was used for analysis. Out of the seven cPAHs investigated only three were detected. They are Benzo (a) Pyrene $(\mathrm{BaP})$, Dibenzo $(\mathrm{a}, \mathrm{h})$ anthracene and Indeno (1, 2, 3-cd) pyrene with soil concentrations of $19.06 \mathrm{mg} / \mathrm{kg}, 6.67 \mathrm{mg} / \mathrm{kg}$ and $29.26 \mathrm{mg} / \mathrm{kg}$ respectively. Their correspondingly individual potency equivalent concentrations in soil $(\mathrm{mg} / \mathrm{kg}$ ) are 19.06, 0.67 and 2.93 respectively. Benzo (k) Fluoranthene, Benzo (a) Anthracene, Benzo (b) Fluoranthene and Chrysene was not detected. The calculated TEQ or TPEC is $22.66 \mathrm{mg} / \mathrm{kg}$ and this value by far exceeds the method B cleanup levels of BaP value of $0.137 \mathrm{mg} / \mathrm{kg}$, it suggests a massively contaminated soil. TPEC is 226.6 times higher than the method B and CAL-EPA risk-based cleanup value of $0.1 \mathrm{mg} / \mathrm{kg}$ while Total cPAHs is 549.9 times higher than the risk-based cleanup value as indicated. This level of soil toxicity with respect to $\mathrm{BaP}$ indicates that the area should be declared a no-go area for humans and animals alike. We strongly recommend the application of Dispersion by Chemical Reaction Technology, should be deployed immediately in this area for total detoxification and decontamination of the area. (C) JASEM
\end{abstract}

http://dx.doi.org/10.4314/jasem/v19i3.20

\section{Introduction}

Many areas in the Niger-delta of Nigeria are adversely affected with crude oil pollution. Nigeria's Niger-delta is one of world's highest producers and reservoirs of crude oil and gas and is also host to diversity of organisms, plants, and animals (AstonJones, 1998). The inhabitants of the area are constantly increasing and are exposed to crude oil contamination. Crude oil is a known major source of Polycyclic Aromatic Hydrocarbons (PAHs), which contains potentially carcinogenic and toxic substances that persist and bioaccumulate in the Environment, with its attendant health consequences (U.S.E.P.A., 1993a).

The Department of Ecology, State of Washington, (2007) reported that Carcinogenic polycyclic aromatic hydrocarbons (cPAHs) are those polycyclic aromatic hydrocarbons (PAHs) identified as Group A (known human) and Group B (probable) carcinogens. The U.S.E.P.A., (1993a) currently identifies seven PAHs as probable human carcinogen (Group B2). Benzo (a) pyrene and some other PAHs generally account for the majority of the risk associated to PAHs. They have been demonstrated to cause Cancer in laboratory animals after repeated dosing.
Regulatory risk assessments are very healthprotective with very low risk based clean-up levels for PAHs are derived for sites (Bradley et al., 1994).

Many polycyclic aromatic hydrocarbons (PAHs) are probable or known carcinogens and mutagens. Benzo (a) pyrene $(\mathrm{BaP})$ is one of the numerous PAHs and the most investigated carcinogenic PAHs (cPAHs). It is accepted to be the most toxic PAH and mostly used as a toxicological prototype for all cPAHs. However, less information is available for most of the other PAHs in terms of potency. In most risk assessments, many individual PAHs have been considered to be of equivalent potency as BaP. This consideration could result in the exaggeration of cancer and mutagen potency of individual PAH because most PAHs are considerably less potent or toxic than $\mathrm{BaP}$ when analyzed in the same way. Many attempts have been investigated to ensure a more reliable risk assessment of potential exposures to mixtures of PAHs. The Potency Equivalency factor (PEF) and Mutagenicity Equivalency Factor (MEF) are mostly used. (Kyung et al., 2010; Durant et al 1999; Durant et al 1996; Nisbet et al., 1992; Marty et al., 1994; Wynder and Hoffman, 1959). 
PEF is an estimate of the relative toxicity of (a) chemical compound(s) to a reference chemical. Environmental soil mixtures of cPAHs use PEF to evaluate the toxicity and assess the risks for the environmental mixtures. PEF methodology rules are often amended to suit current realities. In this way, the mixtures of cPAHs is considered as a single hazardous substance when establishing and determining compliance with cleanup and remediation levels. The use of PEFs values for cPAHs as adopted by the California Environmental Protection Agency, (California EPA, 2005) to characterize the toxicity of these mixtures and use of physico-chemical properties of individual PAHs in evaluating the cross-media impact. Cal-EPA (2005), reported the PEF for the minimum required $\mathrm{CPAHs}$ under WAC/173-340-708(e) and uses $0.137 \mathrm{mg} / \mathrm{kg}$ (which I approximated to $0.1 \mathrm{mg} / \mathrm{kg}$ ), for its riskbased cleanup levels for $\mathrm{BaP}$, (Department of Ecology, State of Washington, (2007)).

Many other risk assessment bodies exist like; MDNR (1993), New Jersey Register, (1992), U.S.E.P.A., (1993b) among others. They use different derived values of risk-based cleanup level for $\mathrm{BaP}$ values of $0.33 \mathrm{mg} / \mathrm{kg}, 0.66 \mathrm{mg} / \mathrm{kg}$ and $0.1 \mathrm{mg} / \mathrm{kg}$ respectively, (Bradley et al., 1994).

The aim of this research is to ascertain the levels of total petroleum hydrocarbons, polycyclic aromatic hydrocarbons and most importantly to determine the total potency equivalent concentration of cPAHs in soils of Bodo-city, River State of Nigeria, using Potency equivalency factor (PEF) model.

\section{MATERIALS AND METHODS}

Description of Study Area.Geographically, the study site, Bodo-city, falls within the geographical axis of latitude $6^{0} 73^{\prime} \mathrm{N}$ and longitude $5^{0} 33^{\prime} \mathrm{E}$. Bodo comprises of 36 villages in Gokana Local Government Area, Rivers state in Nigeria. The occupation of the inhabitants are farming and fishing.

For analysis of Total Petroleum Hydrocarbon, gas chromatographic (GC) system was used. Total petroleum hydrocarbons were analyzed by capillary gas chromatography model HP 5890 series, the gas chromatography system is equipped with flame ionization detector.

For analysis of Polycyclic Aromatic Hydrocarbons, a HP 5870 Gas Chromatography was used, this HP 5870 in stark B5 uses flame ionization detectors (FIDs). Because of this, only substances that burn are detected as they elute from the column. The following seventeen PAHs were analyzed as well total petroleum hydrocarbon (TPH); Naphthalene, 2Methyl Naphthalene, Acenaphthalene, Acenaphthene, Fluorene, Phananthrene, Anthracene, Fluoranthene, Pyrene, Benzo (a) Anthracene, Chrysene, Benzo (b) Fluoranthene, Benzo (k) Fluoranthene, Benzo (a) pyrene, Benzo (g,h,i) Perylene, Dibenzo (a,h) Anthracene, Indeno (1,2,3cd) Pyrene. The results obtained were further used evaluate the $\mathrm{cPAHs}$ and determine TEQ.

\section{RESULTS AND DISCUSSION}

The results of the analysis are presented in Table 1 shows the results of PAHs, TPH and Total cPAHs and table 2. Indicates the calculated Total Potency equivalent concentration $(\mathrm{mg} / \mathrm{kg})$ in soil of the detected cPAHs

Table 1: Levels $(\mathrm{mg} / \mathrm{kg})$ of PAHs, TPH and Total cPAHs in soil samples obtained from Bodo-city.

\begin{tabular}{lc}
\hline \multicolumn{1}{c}{ Name } & Amount $(\mathrm{mg} / \mathrm{kg})$ \\
\hline Naphthalene & 958.89379 \\
2-Methyl Naphthalene & 7.738681 \\
Acenaphthalene & 22.66791 \\
Acenaphthene & 8.10856 \\
Fluorene & 34.46815 \\
Phananthrene & 0.00000 \\
Anthracene & 0.00000 \\
Fluoranthene & 0.00000 \\
Pyrene & 0.00000 \\
Benzo (a) Anthracene & - \\
Chrysene & - \\
Benzo (b) Fluoranthene & - \\
Benzo (k) Fluoranthene & - \\
Benzo (a) pyrene & 19.05571 \\
Benzo (g,h,i) Perylene & 10.05614 \\
Dibenzo (a,h) Anthracene & 6.67448 \\
Indeno (1,2,3-cd) Pyrene & 29.26252 \\
Total PAHs & 1089.96111 \\
TPH & 2430.46 \\
Total cPAHs & 54.99 \\
\hline
\end{tabular}

Table 1 indicates that seventeen PAHs that were evaluated as well as TPH. The total PAHs and values of cPAHs were also indicated as shown in the table above. Out of seventeen PAHs screened nine were detected, while eight were not detected as indicated in the table. Out of seven known cPAHs screened, three were detected while four were not detected as shown in the table above. The values in $\mathrm{mg} / \mathrm{kg}$ of the Total PAHs, TPH and total cPAHs are 1089.96, 2430.46 and 54.99 respectively. The order concentrations $(\mathrm{mg} / \mathrm{kg})$ of the detected PAHs in the samples are $958.89>34.47>29.26>22.62>19.06$ $>10.06>8.11>7.74>6.67$ respectively for Naphthalene, Fluorene, Indeno (1,2,3-cd) Pyrene, Acenaphthalene, Benzo (a) pyrene, Benzo (g,h,i) Perylene, Acenaphthene, 2-Methyl Naphthalene and Dibenzo (a,h) Anthracene. Phananthrene, Anthracene, Fluoranthene, Pyrene, Benzo (a) Anthracene, Chrysene, Benzo (b) Fluoranthene, and 
Benzo (k) Fluoranthene were not detected as indicated in above table.

Table 2 and figure 1 conveys the same information, while table 2.0 below shows the calculated values of the Total Potency equivalent concentration $(\mathrm{mg} / \mathrm{kg})$ in soil of cPAHs using the TEF model. Figure 1 shows the graphical representations in a chart.

Table 2: Calculated Total Potency equivalent concentration $(\mathrm{mg} / \mathrm{kg})$ in soil of cPAHs

\begin{tabular}{lll}
\hline \multicolumn{1}{c}{ (cPAHs) } & $\begin{array}{l}\text { Individual cPAHs } \\
\text { concentration }(\mathrm{mg} / \mathrm{kg}) \text { in soil }\end{array}$ & $\begin{array}{l}\text { Potency equivalent concentration } \\
\text { in soil }(\mathrm{mg} / \mathrm{kg})\end{array}$ \\
\hline Benzo (a) pyrene & 19.06 & 19.06 \\
Benzo (a) Anthracene & - & - \\
Benzo (b) Fluoranthene & - & - \\
Benzo (k) Fluoranthene & - & - \\
Chrysene & - & - \\
Dibenzo (a,h) Anthracene & 6.67 & 0.67 \\
Indeno (1,2,3-cd) Pyrene & 29.26 & 2.93 \\
Total & 54.99 & TEQ OR TPEC $=22.66$ \\
\hline
\end{tabular}

The cleanup levels and risk calculation using the Model Toxic Control Acts (MTCA) was strictly followed in the calculation of TEQ or TPEC. The Potency equivalent concentration in soil in $\mathrm{mg} / \mathrm{kg}$ for the individual cPAHs i.e., Benzo (a) pyrene, Benzo (a) Anthracene, Benzo (b) Fluoranthene, Benzo (k) Fluoranthene, Chrysene, Dibenzo (a,h) Anthracene and Indeno (1,2,3-cd) Pyrene are 19.06, 0, 0, 0, 0,
0.67 and 2.93 respectively. These individual values are however not enough and must be considered as a unit hazardous substance in attempt to determine or establish if the site needs. The TEQ or TPEC for the cPAHs being $22.66 \mathrm{mg} / \mathrm{kg}$ in this specified soil sample from Bodo-city exceeds by far the method B cleanup levels for $\mathrm{BaP}$, i.e. $0.137 \mathrm{mg} / \mathrm{kg}$, which is approximately $0.1 \mathrm{mg} / \mathrm{kg}$.

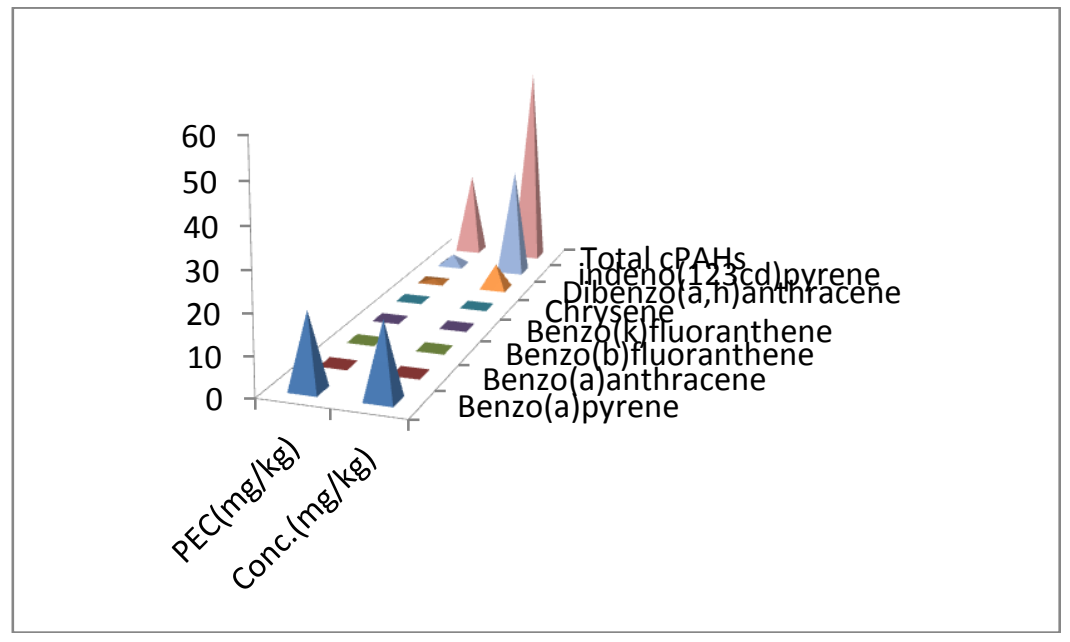

Fig 1 Showing individual cPAHs and Total cPAHs (TcPAHs) in soil samples from Bodo-city

This implies that the cleanup level has not been met for this specified soil sample in Bodo area, hence massive cleanup and efficient remediation strategy should be adopted. The primary occupation and economic activities of the inhabitants of this area are severely affected as soil and surroundings Rivers are polluted. 


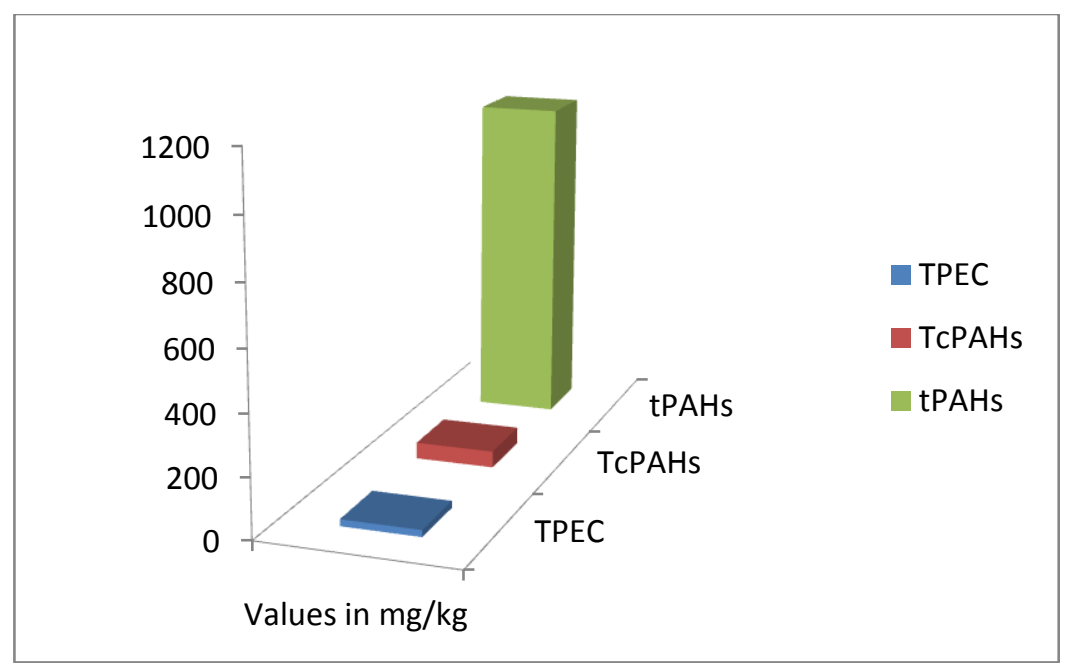

Fig. 2. Representation of TPEC, TcPAHs, and tPAHs

Figure 2, shows the graphical representation of TPEC, Total cPAHs and tPAHs. TcPAHs is more than 2.4 times greater than TPEC and represents about $5.04 \%$ of the tPAHs, while TPEC represents $2.08 \%$ of tPAHs of the site in question. The sites
TPEC is very high when compared some other and earlier noted risk-based values like $0.33 \mathrm{mg} / \mathrm{kg}$ for MDNR (1993), 0.66mg/kg for New Jersey Register and $0.1 \mathrm{mg} / \mathrm{kg}$ for USEPA (1993b) cleanup levels for $\mathrm{BaP}$

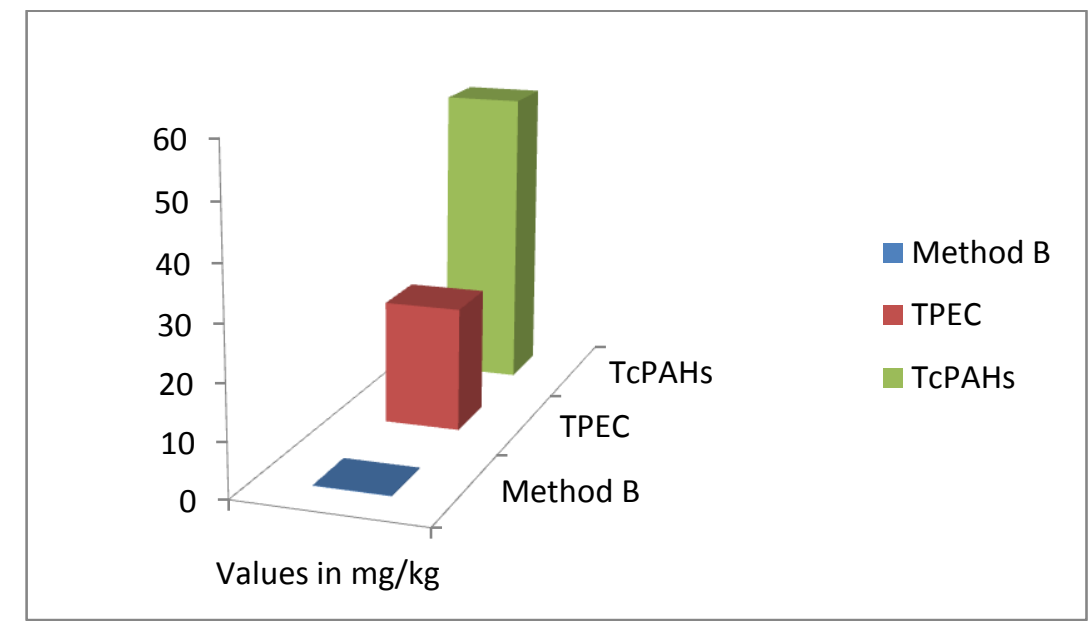

Fig. 3 Total cPAHs, TPEC and Method B-based standard

Figure 3 shows the graphical representations of method B cleanup based standard of $0.137 \mathrm{mg} / \mathrm{kg}$ which was approximated to $0.1 \mathrm{mg} / \mathrm{kg}$, TPEC and Total cPAHs. TPEC is 226.6 times higher than both method B and the CAL-EPA (2005) risk-based cleanup value of $0.1 \mathrm{mg} / \mathrm{kg}$ while TcPAHs is 549.9 times higher than the method $\mathrm{B}$ and risk-based cleanup value as indicated.

Conclusion Out of the seven cPAHs investigated only three were detected namely; $\mathrm{BaP}$, Dibenzo (a,h) anthracene and Indeno (1,2,3-cd) pyrene with concentrations of $19.06 \mathrm{mg} / \mathrm{kg}, 6.67 \mathrm{mg} / \mathrm{kg}$ and 29.26 $\mathrm{mg} / \mathrm{kg}$ respectively, their individual potency equivalent concentration in soil in $\mathrm{mg} / \mathrm{kg}$ are 19.06 , 0.67 and 2.93 respectively. Benzo (k) Fluoranthene, Benzo (a) Anthracene, Benzo (b) Fluoranthene and Chrysene were not detected. This implies that the TEQ or TPEC is $22.66 \mathrm{mg} / \mathrm{kg}$ and when correlated with method $\mathrm{B}$ cleanup levels for $\mathrm{BaP}$ values of $0.137 \mathrm{mg} / \mathrm{kg}$, it suggests a massively contaminated soil. This level of soil toxicity with respect to $\mathrm{BaP}$ indicates the area should be declared a no-go area for man and animals alike. The application of Dispersion 
by Chemical Reaction Technology should be deployed in this area for total decontaminated and detoxification of the area is highly recommended.

AcknowledgementsWe remain grateful to Dr. Osakwe for assisting in conducting preliminary and final analysis in his laboratory.

\section{REFERENCES}

Aston-Jones, N (1998). The Human Ecosystem of the Niger Delta: An Era Handbook, Environmental Rights action, Benin-City, pp. 51-161.

Blumer, M; Blumer, W; Reich, T (1977). Polycyclic Aromatic Hydrocarbons in Soils of a Mountain Valley: Correlation with Highway Traffic and Cancer Incidence. Work at Woods Hole supported by the Office of Naval Research (NOO-14-66 Contract CO-241) and the National Science Foundation (Grant DES 74-22781).

Bradley, L J N: Magee, B H: Allen, S L (1994). Background levels of PAHs and selected metals in New England Urban Soil. Journal of soil contamination, 3(4).

California Environmental Protection Agency, (2005). Air toxic hot spots program risk assessment guidelines, part II technical support document for describing available cancer potency factors. Office of environmental health hazard assessment. California Environmental protection Agency.

Department of Ecology, State of Washington, (2007). Evaluating the Toxicity and Assessing the Carcinogenic Risk of Environmental Mixtures Using Toxicity Equivalency Factors.

Durant, J: Busby, W: Lafleur, A: Penman, B: Crespi, C. (1996). Human cell mutagenicity of oxygenated, nitrated and unsubstituted polycyclic aromatic hydrocarbons associated with urban aerosols. Mutat. Res.-Genet. Tox. 371, 123-157.

Durant, J: Lafleur, A: Busby, W: Donhoffner, L: Penman, B: Crespi, C. (1999). Mutagenicity of $\mathrm{C}_{24} \mathrm{H}_{14}$ PAH in human cells expressing CYP1A1. Mutat. Res.-Genet. Toxicol. E. M. 446, 1-14.

Kyung, H J: Beizhan Y: Steven, N C: Frederica, P P: Robin, W: David, C: Patrick, L K: Rachel, L M (2010). Assessment of Benzo (a) pyreneequivalent Carcinogenicity and Mutagenicity of Residential Indoor versus Outdoor Polycyclic
Aromatic Hydrocarbons Exposing Young Children in New York City. Int. J. Environ. Res. Public Health , 7, 1889-1900; doi:10.3390/ijerph7051889

Marty, M A: Alexeeff, G V: Collins, J F: Blaisdell, R J: Rosenbaum, J: Lee, L (1994). Airborne emissions from industrial point sources and associated cancer risks of selected carcinogens in California. In The Emissions Inventory: Perception and Reality Proceedings of an International Specialty Conference; Air \& Waste Management Association: Pittsburgh, PA, USA, pp. 1086-1097.

Massachusetts Department of Environmental Protection. (1992). Risk Assessment Short Form. Boston, MA, Office of Research and Standards and the Bureau of Waste Site Cleanup, Massachusetts Department of Environmental Protection.

Michigan Department of Natural Resources. (1993). MERA Operational Memorandum \#8, Revision 2. July 16.

New Jersey Register. (1992). Site Remediation Program. Cleanup Standards for Contaminated Sites. Proposed New Rules: NJAC 7:26D. C24:373. Monday, February 3.

Nisbet, I: LaGoy, P: (1992). Toxic equivalency factors (TEFs) for polycyclic aromatic hydrocarbons (PAHs). Regul. Toxicol. Pharmacol. RTP, 16, 290-300.

U.S. EPA. (1993a). Integrated Risk Information System (IRIS). Cincinnati, OH, Environmental Criteria and Assessment Office, U.S. Environmental Protection Agency.

U.S. EPA. (1993b). Risk-Based Concentration Table, Third Quarter. U.S. Environmental Protection Agency, Region III.

Wynder, E: Hoffmann, D (1959). A study of tobacco carcinogenesis. X. Tumor promoting activity. CA-Cancer J. Clin., 24, 289-301. 